\title{
Coulisses
}

Revue de théâtre

4 | Été 1991

Varia

\section{Pinocchio ou La Cité cornu}

de Wladyslaw Znorko créé au festival d'Avignon 1990

\section{Laurence Gainet}

\section{CpenEdition}

Journals

Édition électronique

URL : http://journals.openedition.org/coulisses/1672

DOI : $10.4000 /$ coulisses. 1672

ISSN : 2546-9460

Éditeur

Presses universitaires de Franche-Comté

\section{Édition imprimée}

Date de publication : 1 juin 1991

Pagination : 4-5

ISSN : $1150-594 \mathrm{X}$

\section{Référence électronique}

Laurence Gainet, «Pinocchio ou La Cité cornu », Coulisses [En ligne], 4 | Été 1991, mis en ligne le 04 juillet 2017, consulté le 21 octobre 2019. URL : http://journals.openedition.org/coulisses/1672 ; DOI : 10.4000/coulisses. 1672

Ce document a été généré automatiquement le 21 octobre 2019

Coulisses 


\section{Pinocchio ou La Cité cornu}

de Wladyslaw Znorko créé au festival d'Avignon 1990

\section{Laurence Gainet}

1 Surprise devant ce défilé de tableaux insolites.

Ne pas essayer de comprendre.

Échappées de mots étranges, bribes de phrases insensées, cris, chants,

qui se mêlent et créent un nouveau langage :

celui du rêve, de l'imaginaire, du voyage.

Un langage universel est né.

Pinocchio! Pinocchio!

Lui, nous le reconnaissons.

Il s'anime sur scène et se réveille en nous.

À nous de jouer!

À nous d'imaginer des histoires

au sein d'un décor extraordinaire et d'une lumière irréelle.

À nous de faire d'un simple objet l'objet de nos rêves.

Ces pantins, ces vieilles poupées, ce soldat

de plomb deviennent les personnages de

notre imagination et vivent à travers nous.

Dans un paysage onirique,

les mises en scène se succèdent,

spectaculaires et clownesques sur

une musique tour à tour envoûtante et dérangeante.

Le théâtre est à nous.

Mémoire : miroir de notre enfance.

Enfance perdue ou enfance retrouvée?

Élans et chutes.

Mélancolie et fête triste effacent

les explosions de joie et l'extase première.

Ampoules colorées d'un bonheur rêvé

au sein de la nuit, de la noire réalité.

Lumières artificielles, déguisements : invitation au voyage. 
Prendre le train, partir, fuir cette réalité, rêver, rêver, et danser avec Pinocchio...

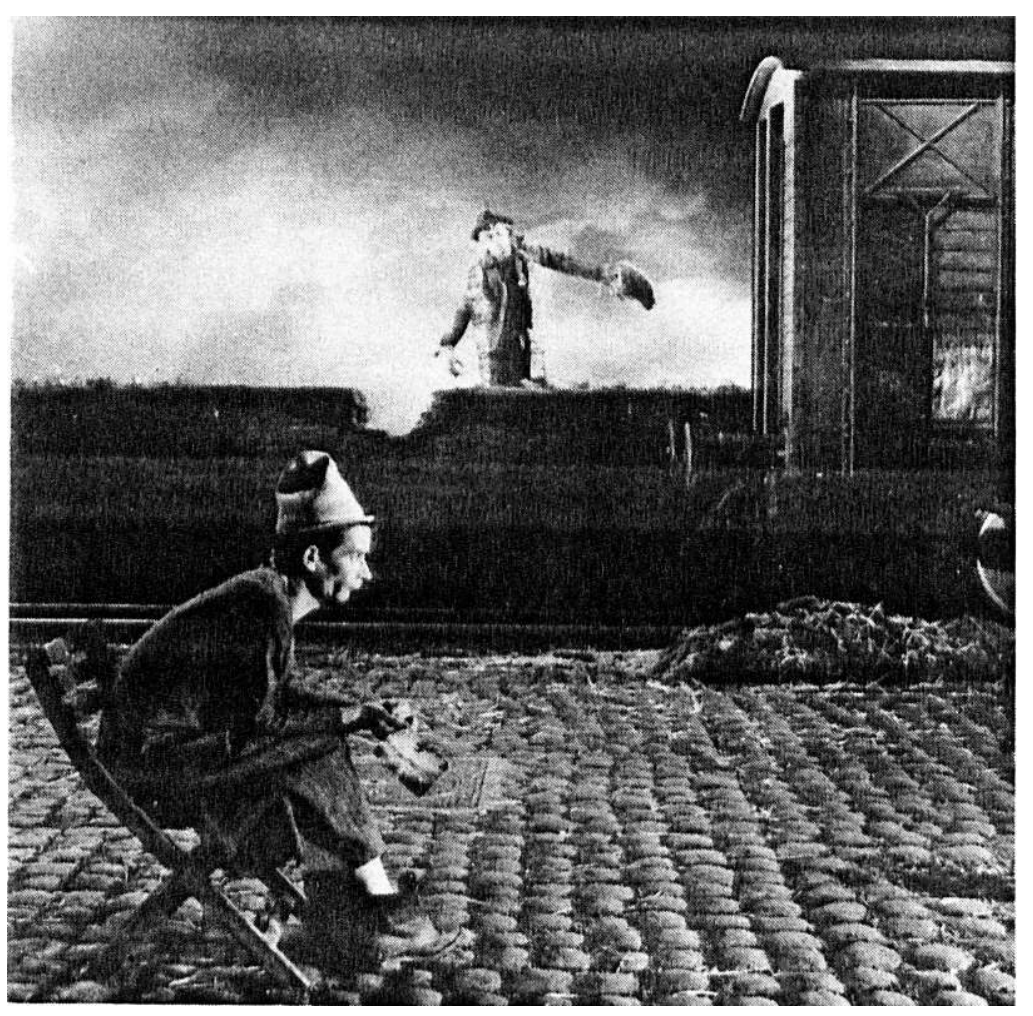

Photo D. Anemian. 